Review

\title{
The Two-Year Rodent Carcinogenesis Bioassay Will It Survive?
}

\author{
Jerrold M. Ward ${ }^{1}$ \\ ${ }^{1}$ Comparative Medicine Branch, National Institute of Allergy and Infectious Diseases, National Institutes of Health, \\ Bethesda, Maryland 20892-8135 USA
}

\begin{abstract}
For over 35 years, many synthetic and natural chemicals have been tested by government agencies, private companies and research institutes for carcinogenic activity in rats and mice in classical 2 year studies as part of a toxicity profile ultimately used for human toxicity and carcinogenicity risk assessment. With an increasing number of pharmaceutical and agricultural chemicals shown to be carcinogenic in these bioassays, research into the mechanisms of toxicity and carcinogenesis has intensified. The relevance of the induced tumors in rodents has been questioned after much research. Research has provided evidence to some scientists that doses used in the bioassays may represent situations where toxicity pathways do not develop in humans exposed to levels of these chemicals, toxicity itself may create situations where tumors develop only under those situations, species specific responses may exist, and tumors induced may not be relevant to human risk. Regulatory agencies have considered these and other factors when preparing regulatory decisions on regulation of these chemicals. Thus, the USA FDA often has approved drugs despite their carcinogenicity in rodents and the USA EPA has explored many situations where considerations of the mechanisms of carcinogenesis in rodents and humans play a role in their regulatory decisions. Unfortunately, much of the decisions are based on unproven and hypothetical mechanisms of carcinogenesis in rodents and humans. Despite this situation, the impact of these decisions on future considerations and decisions for regulation of chemicals suggests that the US regulatory agencies consider that the occurrence of increased incidences of tumors in standard 2 year rodent carcinogenesis bioassay is often not relevant to human carcinogenesis risk assessment.
\end{abstract}

(J Toxicol Pathol 2007; 20: 13-19)

Key words: bioassay, carcinogenesis, rodents, toxicology

\section{Introduction}

Natural and manmade chemicals have been evaluated for their toxicity in rats and mice for over 40 years in order to provide information to be used for estimating risks to humans. Of particular popularity has been the 2 year carcinogenesis bioassay. It has always been assumed that the acute and chronic toxicity of a specific chemical in rodents has relevance to the risk of acute and chronic toxicity and carcinogenesis in humans. With the discovery of the toxicity of chemicals found naturally in the environment and the growth of the pharmaceutical industry during the past 20 years, it has become evident that there are numerous toxins and rodent carcinogens that humans are exposed to on a daily basis. The relevance of the carcinogenicity findings in rats and mice to human risk has been investigated, reviewed and challenged in many publications by individuals, institutions

Received: 26 December 2006, Accepted: 16 January 2007

Mailing address: Jerrold M. Ward, CMB, NIAID, NIH, Bethesda, MD 20892-8135 USA

TEL: 1-301-402-5620 FAX: 1-301-480-2343

E-mail: jw116y@nih.gov and scientific committees during the past ten years ${ }^{1-9}$. The federal regulatory agencies in the United States and other countries have responded. Numerous drugs that have caused tumors in rodents in 2 year carcinogenesis bioassays are on the market, approved for use by the regulatory agency responsible for assessing efficacy and safety ${ }^{10,11}$. The EPA evaluates mechanism of carcinogenesis of environmental agents prior to approving their use. This review will present the major issues involved.

\section{History of the Bioassay}

Chemicals in our environment include pharmaceutical agents, food additives, industrial intermediates, agricultural chemicals, natural endogenous and exogenous chemicals and air pollutants. Most are potentially toxic to living creatures including wild animals, insects, laboratory rodents, domesticated animals and humans. Since Percivall Pott showed that chimney soot was associated with scrotal cancer and Yamigiwa \& Ichikawa first showed that coal tar could cause skin cancer in rabbits, it was assumed that chemicals that humans are exposed to may lead to toxic and carcinogenic hazards ${ }^{12,13}$. Thus, the various federal 
government regulatory agencies developed rules and regulations for chemicals that humans may be exposed to at work, in the air, at home, in food and medications. Much of these regulations accelerated in the 1970s when agricultural chemicals were found to be carcinogenic in rodents. At first simple bioassays were developed which exposed rats or mice to a test chemical in the diet, by gavage or by inhalation for up to 2 years ${ }^{13}$. Chemicals were given usually at 2 doses and controls were used. The highest doses were at a maximally tolerated level, which was subsequently defined as a dose which would produce not more than $10-15 \%$ depression in body weight gain, early illness or death due to the chemical. The largest efforts in using, developing and improving these bioassays were first done by The US National Cancer Institute in the 1970s until the formation of The National Toxicology Program under the leadership of the National Institute of Environmental Health Sciences in the late $1970 \mathrm{~s}^{14}$. Since that time, various guidelines have been developed by regulatory agencies and have evolved for use in requirements for carcinogenesis testing in the USA and other countries (The US FDA Redbook (http://www.cfsan.fda.gov/ $\sim$ redbook/red-ivc6.html); the US EPA guidelines for carcinogenicity risk assessment, http://epa.gov/iris/ cancer032505.pdf; European and international guidelines, http://www.emea.europa.eu/htms/human/ich/ichsafety.htm). Some old concepts still exist, however, such as The Delaney Clause of the Federal Food Drug and Cosmetic Act of 1958 which states that no additive will "be deemed safe if it is found to induce cancer when ingested by man or animal." 15 . Advances in using rodents for human carcinogenesis risk assessment have been suggested ${ }^{16}$.

Since that time, over 500 chemicals were tested for toxicity and carcinogenesis by the US government and probably over 1500 chemicals by various sponsors throughout the world ${ }^{17-20}$. The International Agency for Research in Cancer (IARC) and its expert committees have reviewed data on over 900 agents (http://monographs.iarc.fr/). This large amount of accumulated data has led to questions concerning the validity of the standard 2 year bioassay for uses in human risk assessment ${ }^{2,21-30}$. Most recently, modifications in standard procedures have been suggested and used by many interested parties ${ }^{31-33}$.

\section{The Rodent Carcinogens and Pathology of Rodent Tumors}

Over the past 50 years, many chemicals (probably thousands) have been shown to cause tumors in rodents with laboratory experiments (by oral administration, injection of newborns or adults, inhalation, or gavage) of short or long term even up to the lifetime of the animals. These studies have induced tumors in various tissues most commonly in liver, lung, skin and mammary gland ${ }^{17,20}$.

Naturally occurring tumors of rats and mice occur in a sex, age and strain or stock dependent manner. Those of the most common strains and stocks of mice (CD-1, B6C3F1) and rats (F344, Sprague-Dawley) used in toxicology have been characterized as to incidence and pathology including natural history ${ }^{34-38}$. Rodents do not commonly develop spontaneous tumors most prevalent in humans including those of the colon and prostate, in part, due to differences in genetics, diet, specific natural chemical exposures and infectious agents.

Naturally occurring and induced tumors of rats and mice progress through a sequence of histomorphologic and when known, molecular events ${ }^{38}$. In epithelial tissues the first visible evidence of neoplastic progression is a focal proliferative lesion followed by focal nodular lesions and benign neoplasia. Benign neoplasia can progess to malignant neoplasia, especially in skin, liver, and lung. Epithelial lesions lining tubular organs often develop dysplastic lesions which can progress to malignancy. The rodents lesions are not unlike those observed in humans except for the more common benign tumors progressing to malignancy in rodents. Also, some normal rodent tissues (especially mammary gland and prostate) and rodent tumors often have less stroma than do their human counterparts. Some scientists have suggested over the years that rodent tumors were, in fact, not tumors but lesions of hyperplasia and reactivity to toxic damage of an organ ${ }^{1,39}$.

\section{The Human Carcinogens}

Many chemicals or processes, viruses, bacteria, parasites, and irradiation have been associated with increased cancer risk in humans, as studied by epidemiological investigations (http://monographs.iarc.fr/ENG/Classification/ index.php, http://ntp-server.niehs.nih.gov/ntpweb) $)^{28,40}$. Most all of these chemicals or processes cause tumors in rats or mice 28,41 . IARC reports that 400 agents have been identified as carcinogenic or potentially carcinogenic to humans (www.iarc.fr). Many of these chemicals, but not all of them, are multiple organ rodent carcinogens and most are genotoxic ${ }^{28}$. Human cancer drugs carry increased risk for secondary cancers $10-30$ years later (www.iarc.fr, IARC monographs, volumes 50 and 66).

\section{Human Pharmaceutical Agents are Often Rodent Carcinogens}

In light of the great expansion of the pharmaceutical industry over the past 30 years, many drugs have been developed for promoting human health. During this development, many prospective drugs have been found to be carcinogenic in 2 year rodent studies. Despite these findings, the drugs are often approved based on important efficacy in humans and risk/benefit analysis by FDA for use in humans, either as prescription drugs or over the counter. Many advisory committees in the USA provide guidance to the US regulatory agencies. For reasons that are not published, the regulatory agencies have approved for human use many drugs which cause tumors in rodent studies ${ }^{11}$. Fortunately, most of these drugs are not genotoxic. Regulatory agencies use rules, regulations and guidelines for 
Table 1. Cholesterol-Lowering Drugs Are Rodent Carcinogens

\begin{tabular}{|c|c|c|c|c|}
\hline Generic name & Trade name & Web Site & Tumors in rats & Tumors in mice \\
\hline Atorvastatin & Lipitor & www.lipitor.com & Sarcomas & Liver \\
\hline Clofibrate & none & www.greatvistachemicals.com & Liver & Liver \\
\hline Colesevelan & Welchol & www.welchol.com & Pancreas, thyroid & none \\
\hline Fenofibrate & Tricor & www.tricortablets.com & Liver, pancreas, testis & Liver \\
\hline Fluvastatin & Lescol & www.pharma.us.novartis.com & Stomach, thyroid & Stomach \\
\hline Gemfibrozil & Lopid & www.gemfibrozil.com & Liver, testis & none \\
\hline Lovastatin & Mevacor & www.merck.com & Liver, thyroid & Liver, lung, stomach \\
\hline Pravastatin & Pravachol & www.bms.com/landing/data & Liver & Liver, lung \\
\hline Rosuvastatin & Crestor & www.astrazeneca-us.com & Uterine polyps & Liver \\
\hline Simvastatin & Zocor & www.zocor.com & Thyroid, liver & Liver, lung, harderian gland \\
\hline
\end{tabular}

Most information is not published in referred journals but is available in product sheets.

Table 2. Carcinogenicity Bioassay of Some Other Popular Pharmaceuticals

\begin{tabular}{llll}
\hline Generic name & Trade name & \multicolumn{1}{c}{ Web Site } & Tumors in rats \\
\hline Acetaminophen & Acetaminophen & www.drugs.com/acetaminophen.html & none \\
Azithromycin & Zithromax & www.zithromax.com & NT \\
Clopidogrel & Plavix & www.plavix.com & none \\
Formoterol fumarate & Foradil & www.pharma.us.novartis.com & Ovary \\
Furosemide & Lasix & www.rxlist.com & none \\
Ibuprofen & Ibuprofen & www.drugs.com/ibuprofen.html & NT \\
Imatinib mesylate & Gleevec & www.gleevec.com & Kidney, bladder, preputial gl \\
Lansoprazole & Prevacid & www.prevacid.com & Testis, stomach \\
Letrozole & Femara & www.femara.com & Ovary \\
Lisinopril & Prinivil, Zestril & www.lisinopril.com & Testis, liver \\
Metoprolol & Lopressor & www.pharma.us.novartis.com & none \\
Salmeterol xinafoate & Serevent & www.fda.gov/medwatch & Uterus \\
Sertraline & Zoloft & www.zoloft.com & Thyroid, uterus \\
\hline
\end{tabular}

NT, not tested in 2 year study.

Most information is not published in referred journals but is available in product sheets.

approval of new drugs for doses given to rodents in 2 year studies which have been many times above the normal human therapeutic doses ${ }^{42}$. Rarely, the rodent carcinogenic dose is only 1-3 times the human therapeutic dose. Many rodent carcinogens are FDA-approved drugs, primarily prescription drugs $s^{4,10,21,43-45}$. Some examples of commonly approved drugs which have been shown to cause rodent tumors in bioassays are shown in Tables 1 and 2. Some of the drugs are multiple organ carcinogens in rodents and a few studies included doses barely above the human therapeutics dose. The information on toxicity or carcinogenicity in rodents is often obtained only from product inserts rather than from published reports.

\section{Mechanisms of Carcinogenesis in Rodents and Humans}

Abundant research has provided evidence that chemicals may cause (induce) tumors in animals and humans by one of several general mechanisms, most commonly referred to as genotoxic and non-genotoxic ${ }^{46}$. Also, more than one mechanism may be found for any target site. Genotoxic chemicals may cause tumors by directly or indirectly damaging DNA, and a genetic change that may eventually end in neoplasia. Genotoxic chemicals can also be toxic at high doses causing tissue damage that may also contribute to promotion of carcinogenesis, perhaps initiated by DNA damage. Nongenotoxic carcinogens are often given at high toxic doses to rats and mice causing chronic target organ toxic lesions which are suggested to be the cause of tumors found in these tissues after chemical exposure ${ }^{1,5,25,29,47-50}$. Associated with chronic toxicity is often chronic regenerative lesions with enhanced cell proliferation and turnover. This finding has lead to hypotheses that the increased rate of cell proliferation and other mechanisms involved in chronic disease promote carcinogenesis in rodents and humans ${ }^{51}$. Other suggested mechanisms in rodent liver include induction of receptors and enzymes, metabolic overload, hormone perturbation, and cytotoxicity ${ }^{52}$. Variability and high incidences of tumors in controls have also been indicated as rodent bioassays problems ${ }^{53}$. These nongenotoxic agents have been suggested to promote naturally occurring tumors, as well, perhaps in tissues with high spontaneous rates of tumors ${ }^{1}$. 
Table 3. Example of Tumor Induction in Rodent Carcinogenesis Bioassays for Which the Postulated Mechanism of Carcinogenesis in Rodents is Suggested to be not Relevant to Humans

\begin{tabular}{llll}
\hline Tissue & Postulated Confounding Factor & \multicolumn{1}{c}{ Examples } & References \\
\hline Blood vessels & Toxicity & 2-butoxyethanol & 77 \\
Bone & Retrovirus & Chronic toxicity & 63 \\
Forestomach & Irritation & BHA & $69,70,81$ \\
Harderian gland & Tissue not found in humans & & 68 \\
Hematopoietic system & High incidence in controls & Lymphomas & 74,75 \\
Kidney & Alpha 2u globulin & Male specific toxicity, cell proliferation & $49,71,72$ \\
Liver & Toxicity & Enzyme inducers, toxicity & $39,52,65$ \\
Lung & Different tumor type than in humans & many & 1 \\
Oral cavity & Toxicity & Chronic toxicity & 76 \\
Nasal cavity & Toxicity & Chronic toxicity & 58 \\
Preputial/Clitoral gland & Tissue not found in humans & & 68 \\
Skin & Sensitive skin in inbred mice & Shaving skin & 1 \\
Testis & High incidence in controls & Endocrine & 94 \\
Thyroid & Pituitary-thyroid axis & Rodent-specific endocrine effects & $23,71,78$ \\
Urinary bladder & Stones, inflammation & Chronic damage, cell proliferation & 24,71 \\
Zymbal's gland & Tissue not found in humans & & 68 \\
\hline
\end{tabular}

Yet, others have shown that many toxins cause chronic tissue damage sometimes with proven chronic cell proliferation that is not associated with increased carcinogenesis in humans and animals ${ }^{54-58}$. The alpha $2 \mathrm{u}$ globulin hypothesis for male rats seems to be related to the low incidences of renal tumors induced; yet some scientists have shown that renal toxicity induced by these chemicals is sometimes not associated with renal carcinogenesis ${ }^{59}$. Others have found that renal toxins often are not renal carcinogens in 2 year bioassays ( $\mathrm{J}$ Ward, unpublished observations).

Other research has reported that the potential mechanism of target organ toxicity and/or carcinogenesis in rodents is not relevant to humans ${ }^{1-4,11,23,25,60-62}$. These include tumors in many tissues including bone ${ }^{63}$, liver ${ }^{52,64-67}$, lung, forestomach ${ }^{68-70}$, urinary bladder ${ }^{23,24,71}$, kidney ${ }^{49,72,73}$, hematopoietic tissues ${ }^{74,75}$, Harderian gland ${ }^{68}$, preputial and Zymbal's glands $^{68}$, oral cavity ${ }^{76}$, endothelium ${ }^{77}$ and the endocrine ${ }^{71,78}$ and reproductive systems (Table 3). Others have shown, however, that toxicity of drugs in humans and animals are concordant ${ }^{79}$ and that misconceptions have been reported concerning these postulated mechanisms ${ }^{27}$.

The USA EPA proposed to classify thyroid carcinogens by possible mechanism (Hill). More recently, EPA cancer guidelines (http://cfpub.epa.gov/ncea/cfm/ recordisplay.cfm?deid $=116283$ ), shows guidelines that allows EPA to make regulatory decisions concerning potential modes of action of a chemical to cause tumors and its relevance to humans, even if all aspects of the evaluation are based on hypothetical and unproven modes of action. Yet, no one has proven that any chemical causes tumors, benign or malignant, specifically by any one or more of the mechanisms hypothesized. This phenomenon may be especially relevant when the postulated mode of action also occurs in studies where no target organ carcinogenesis is seen despite target organ toxicity ${ }^{54-56,58}$.
The International Agency for Research in Cancer (IARC) has suggested that chemicals that cause tumors in rodents may do so by mechanisms that do not operate in humans (http://monographs.iarc.fr/ENG/Preamble/ index.php).

An expert committee and other groups and individuals have recently suggested a human relevance framework for analyzing rodent carcinogenesis data ${ }^{23,52,60,65,80-82}$. The analysis attempts to postulate a mode of action (MOA) for the rodent carcinogenesis of a specific chemical. After it is defined, an analysis of the MOA in human is assessed based on the weight of the evidence. For genotoxic agents, a comparative mechanism of carcinogenesis in rodents may be more plausible than for non-genotoxic agents at doses for which humans are exposed and for which no comparative toxic histopathologic lesions are induced in humans.

\section{Alternatives to the 2 Year Rodent Carcinogenesis Bioassay}

Scientists and others have offered many alternatives to rat and mouse toxicity tests including 2 year carcinogenesis bioassays $\left({ }^{83}\right.$, http://iccvam.niehs.nih.gov). These have included the use of no rodents (http:// www.stopanimaltests.com/u-ntp.asp), in vitro cell transformation and other assays, mutagenesis tests, computerized prediction of carcinogenicity of a chemical based on structure and chemical class ${ }^{84}$, use of the toxicity level (LD50) in rodents for estimating human carcinogenic risk $^{85}$, the neonatal mouse assay, 6 month genetically engineered mouse assays ${ }^{86-88}$, use of rats only $y^{22}$, female rats and male mice ${ }^{22}$, multi-mouse strain protocols ${ }^{89}$, medium term liver rat bioassays ${ }^{90,91}$, and medium term multi-organ rat bioassays ${ }^{90}$. Each assay has its advantages and disadvantages, perhaps as many as the 2 year assay itself. It is up to the federal regulatory agencies to determine if any of 
these assays will replace the 2 year carcinogenesis bioassay, supplement the 2 year bioassays or not be considered for human risk assessment.

\section{Future Considerations}

Human epidemiological studies often require 20-30 years to establish whether a chemical can cause cancer in humans. Few such studies have been accomplished for present day pharmaceuticals ${ }^{92,93}$. Also, the popularity of specific drugs changes over the years and many are discontinued and replaced by more effective agents. For pesticides, low doses in food, water and the environment, make it difficult to establish any carcinogenic activity of these compounds in humans by epidemiological studies. Cigarette smoking and high industrial exposures provide much more convincing evidence of human carcinogenicity ${ }^{40}$. Thus, we may never know if drugs at therapeutic doses or pesticides at low environmental doses or other chemicals actually cause cancer in humans. The pool of potential carcinogenic agents to which we are exposed grows every year. Will it take an outbreak of a specific cancer 30 years after a drug was introduced to provide evidence of human carcinogenicity or are we essentially safe from these effects from most chemicals that cause tumors in 2 year rodent carcinogenicity bioassays? Thus far, no such evidence has been found.

Acknowledgement: This article was supported in part by a NIAID contract to SoBran, Inc.

\section{References}

1. Anisimov VN, Ukraintseva SV, and Yashin AI. Cancer in rodents: does it tell us about cancer in humans? Nat Rev Cancer. 5: 807-819. 2005.

2. Knight A, Bailey J, and Balcombe J. Animal carcinogenicity studies: 1. Poor human predictivity. Altern Lab Anim. 34: 19-27. 2006.

3. Knight A, Bailey J, and Balcombe J. Animal carcinogenicity studies: 2. Obstacles to extrapolation of data to humans. Altern Lab Anim. 34: 29-38. 2006.

4. Knight A, Bailey J, and Balcombe J. Animal carcinogenicity studies: implications for the REACH system. Altern Lab Anim. 34 Suppl 1: 139-147. 2006.

5. Monro A. How useful are chronic (life-span) toxicology studies in rodents in identifying pharmaceuticals that pose a carcinogenic risk to humans? Adverse Drug React Toxicol Rev. 12: 5-34. 1993.

6. Monro A. Are lifespan rodent carcinogenicity studies defensible for pharmaceutical agents? Exp Toxicol Pathol. 48: 155-166. 1996.

7. Monro A and Mehta D. Are single-dose toxicology studies in animals adequate to support single doses of a new drug in humans? Clin Pharmacol Ther. 59: 258-264. 1996.

8. Monro A and Davies TS. High dose levels are not necessary in rodent studies to detect human carcinogens. Cancer Lett. 75: 183-194. 1993.

9. Monro A. What is an appropriate measure of exposure when testing drugs for carcinogenicity in rodents? Toxicol Appl Pharmacol. 112: 171-181. 1992.

10. Davies $\mathrm{T}$ and A Munro. Marketed human pharmaceuticals reported to be tumorigenic in rodents. J Am Coll Toxicol. 14: 90-107. 1995.

11. Jacobs A and Jacobson-Kram D. Human carcinogenic risk evaluation, Part III: Assessing cancer hazard and risk in human drug development. Toxicol Sci. 81: 260-262. 2004.

12. Pastoor $T$ and Stevens J. Historical perspective of the cancer bioassay. Scand J Work Environ Health. 31 Suppl 1: 129140. 2005.

13. Weisburger EK. History of the Bioassay Program of the National Cancer Institute. Prog Exp Tumor Res. 26: 187201. 1983.

14. Bucher JR. The National Toxicology Program rodent bioassay: designs, interpretations, and scientific contributions. Ann NY Acad Sci. 982: 198-207. 2002.

15. Weisburger EK. Current carcinogen perspectives: De minimis, Delaney and decisions. Sci Total Environ. 86: 513. 1989.

16. Bucher JR and Portier C. Human carcinogenic risk evaluation, Part V: The national toxicology program vision for assessing the human carcinogenic hazard of chemicals. Toxicol Sci. 82: 363-366. 2004.

17. Gold LS, Slone TH, Manley NB, and Bernstein L. Target organs in chronic bioassays of 533 chemical carcinogens. Environ Health Perspect. 93: 233-246. 1991.

18. Gold LS, Manley NB, Slone TH, and Ward JM. Compendium of chemical carcinogens by target organ: results of chronic bioassays in rats, mice, hamsters, dogs, and monkeys. Toxicol Pathol. 29: 639-652. 2001.

19. Freedman DA, Gold LS, and Lin TH. Concordance between rats and mice in bioassays for carcinogenesis. Regul Toxicol Pharmacol. 23: 225-232. 1996.

20. Huff J. Chemicals studied and evaluated in long-term carcinogenesis bioassays by both the Ramazzini Foundation and the National Toxicology Program: in tribute to Cesare Maltoni and David Rall. Ann NY Acad Sci. 982: 208-230. 2002.

21. Knight A, Bailey J, and Balcombe J. Which drugs cause cancer? For BMJ. 331: E389-391. 2005.

22. Alden CL, Smith PF, Piper CE, and Brej L. A critical appraisal of the value of the mouse cancer bioassay in safety assessment. Toxicol Pathol. 24: 722-725. 1996.

23. Cohen SM, Klaunig J, Meek ME, Hill RN, Pastoor T, Lehman-McKeeman L, Bucher J, Longfellow DG, Seed J, Dellarco V, Fenner-Crisp P, and Patton D. Evaluating the human relevance of chemically induced animal tumors. Toxicol Sci. 78: 181-186. 2004.

24. Cohen SM and Lawson TA. Rodent bladder tumors do not always predict for humans. Cancer Lett. 93: 9-16. 1995.

25. Gold L, Slone T, Manley N, and Ames B. Misconceptions about the Causes of Cancer. Frasier Institute, Vancouver. 2003.

26. Anderson LM. Predictive values of traditional animal bioassay studies for human perinatal carcinogenesis risk determination. Toxicol Appl Pharmacol. 199: 162-174. 2004.

27. Tomatis L, Melnick RL, Haseman J, Barrett JC, and Huff J. Alleged misconceptions' distort perceptions of environmental cancer risks. Faseb J. 15: 195-203. 2001.

28. Tomatis L. Identification of carcinogenic agents and primary 
prevention of cancer. Ann NY Acad Sci. 1076: 1-14. 2006.

29. Gold LS, Slone TH, and Ames BN. What do animal cancer tests tell us about human cancer risk?: Overview of analyses of the carcinogenic potency database. Drug Metab Rev. 30: 359-404. 1998.

30. Gaylor DW. Are tumor incidence rates from chronic bioassays telling us what we need to know about carcinogens? Regul Toxicol Pharmacol. 41: 128-133. 2005.

31. Davies TS, Lynch BS, Monro AM, Munro IC, and Nestmann ER. Rodent carcinogenicity tests need be no longer than 18 months: an analysis based on 210 chemicals in the IARC monographs. Food Chem Toxicol. 38: 219-235. 2000.

32. King-Herbert A and Thayer K. NTP Workshop: Animal models for the NTP rodent cancer bioassay: stocks and strains-should we switch? Toxicol Pathol. 34: 802-805. 2006.

33. Galer DM and Monro AM. Veterinary drugs no longer need testing for carcinogenicity in rodent bioassays. Regul Toxicol Pharmacol. 28: 115-123. 1998.

34. Maronpot R. Pathology of the Mouse. Cache River Press, Vienna, IL. 1999.

35. Mohr U, Dungworth DL, and Capen CC. Pathobiology of the Aging Rat. ILSI Press, Washington DC. 1992.

36. Mohr U, Dungworth DL, Capen CC, Carlton WW, Sundberg JP, and Ward JM. Pathobiology of The Aging Mouse. ILSI Press, Washington D.C. 1996.

37. Mohr U. International Classification of Rodent Tumors: The Mouse. Springer, Berlin. 2001.

38. Ward J. Preneoplastic and precancerous lesions in rodents: morphologic and molecular characteristics. J Toxicol Pathol. 15: 123-128. 2002.

39. Butler WH. A review of the hepatic tumors related to mixedfunction oxidase induction in the mouse. Toxicol Pathol. 24: 484-492. 1996.

40. Doll R. The causes of cancer. Rev Epidemiol Sante Publique. 49: 193-200. 2001.

41. Huff J. Long-term chemical carcinogenesis bioassays predict human cancer hazards. Issues, controversies, and uncertainties. Ann NY Acad Sci. 895: 56-79. 1999.

42. Furberg CD, Levin AA, Gross PA, Shapiro RS, and Strom BL. The FDA and drug safety: a proposal for sweeping changes. Arch Intern Med. 166: 1938-1942. 2006.

43. Newman TB and Hulley SB. Carcinogenicity of lipidlowering drugs. Jama. 275: 55-60. 1996.

44. Mehta JL, Bursac Z, Hauer-Jensen M, Fort C, and Fink LM. Comparison of mortality rates in statin users versus nonstatin users in a United States veteran population. Am J Cardiol. 98: 923-928. 2006.

45. Monro AM and MacDonald JS. Evaluation of the carcinogenic potential of pharmaceuticals. Opportunities arising from the International Conference on Harmonisation. Drug Saf. 18: 309-319. 1998.

46. Preston RJ and Williams GM. DNA-reactive carcinogens: mode of action and human cancer hazard. Crit Rev Toxicol. 35: 673-683. 2005.

47. Gold LS, Manley NB, and Ames BN. Extrapolation of carcinogenicity between species: qualitative and quantitative factors. Risk Anal. 12: 579-588. 1992.

48. Clayson DB, Iverson F, and Mueller R. An appreciation of the maximum tolerated dose: an inadequately precise decision point in designing a carcinogenesis bioassay?
Teratog Carcinog Mutagen. 11: 279-296. 1991.

49. Hard GC, Boorman GA, and Wolf DC. Re-evaluation of the 2-year chloroform drinking water carcinogenicity bioassay in Osborne-Mendel rats supports chronic renal tubule injury as the mode of action underlying the renal tumor response. Toxicol Sci. 53: 237-244. 2000.

50. Grasso P, Sharratt M, and Cohen AJ. Role of persistent, nongenotoxic tissue damage in rodent cancer and relevance to humans. Annu Rev Pharmacol Toxicol. 31: 253-287. 1991.

51. Schottenfeld D and Beebe-Dimmer J. Chronic inflammation: a common and important factor in the pathogenesis of neoplasia. CA Cancer J Clin. 56: 69-83. 2006.

52. Holsapple MP, Pitot HC, Cohen SM, Boobis AR, Klaunig JE, Pastoor T, Dellarco VL, and Dragan YP. Mode of action in relevance of rodent liver tumors to human cancer risk. Toxicol Sci. 89: 51-56. 2006.

53. Haseman JK. Using the NTP database to assess the value of rodent carcinogenicity studies for determining human cancer risk. Drug Metab Rev. 32: 169-186. 2000.

54. Hoel DG, Haseman JK, Hogan MD, Huff J, and McConnell EE. The impact of toxicity on carcinogenicity studies: implications for risk assessment. Carcinogenesis. 9: 20452052. 1988.

55. Huff J. Chemical toxicity and chemical carcinogenesis. Is there a causal connection? A comparative morphological evaluation of 1500 experiments. IARC Sci Publ. 116: 437475. 1992.

56. Huff J. Absence of morphologic correlation between chemical toxicity and chemical carcinogenesis. Environ Health Perspect. 101 Suppl 5: 45-53. 1993.

57. Tennant RW, Elwell MR, Spalding JW, and Griesemer RA. Evidence that toxic injury is not always associated with induction of chemical carcinogenesis. Mol Carcinog. 4: 420-440. 1991.

58. Ward JM, Uno H, Kurata Y, Weghorst CM, and Jang JJ. Cell proliferation not associated with carcinogenesis in rodents and humans. Environ Health Perspect. 101 Suppl 5: 125135. 1993.

59. Doi A, Hill G, Selly J, Hailey JR, Kissling G, and Bucher JR. a2u-Globulin nephropathy and renal tumors in National Toxicology Program studies. Toxicol Pathol. 2007 (in press).

60. Seed J, Carney EW, Corley RA, Crofton KM, DeSesso JM, Foster PM, Kavlock R, Kimmel G, Klaunig J, Meek ME, Preston RJ, Slikker W, Jr., Tabacova S, Williams GM, Wiltse J, Zoeller RT, Fenner-Crisp P, and Patton DE. Overview: Using mode of action and life stage information to evaluate the human relevance of animal toxicity data. Crit Rev Toxicol. 35: 664-672. 2005.

61. Silva Lima B and Van der Laan JW. Mechanisms of nongenotoxic carcinogenesis and assessment of the human hazard. Regul Toxicol Pharmacol. 32: 135-143. 2000.

62. Gerson RJ, MacDonald JS, Alberts AW, Kornbrust DJ, Majka JA, Stubbs RJ, and Bokelman DL. Animal safety and toxicology of simvastatin and related hydroxymethylglutaryl-coenzyme A reductase inhibitors. Am J Med. 87: 28S-38S. 1989.

63. Maurer JK, Cheng MC, Boysen BG, Squire RA, Strandberg JD, Weisbrode SE, Seymour JL, and Anderson RL. Confounded carcinogenicity study of sodium fluoride in CD-1 mice. Regul Toxicol Pharmacol. 18: 154-168. 1993.

64. Holden PR and Tugwood JD. Peroxisome proliferator- 
activated receptor alpha: role in rodent liver cancer and species differences. J Mol Endocrinol. 22: 1-8. 1999.

65. Klaunig JE, Babich MA, Baetcke KP, Cook JC, Corton JC, David RM, DeLuca JG, Lai DY, McKee RH, Peters JM, Roberts RA, and Fenner-Crisp PA. PPARalpha agonistinduced rodent tumors: modes of action and human relevance. Crit Rev Toxicol. 33: 655-780. 2003.

66. Ward J, Konishi N, and Ostergaard K. Hepatic lesions in Danish epileptics after long-term exposure to anticonvulsant drugs including phenobarbitone. J Natl Cancer Inst. 81: 1753-1754. 1989.

67. Rusyn I, Peters JM, and Cunningham ML. Modes of action and species-specific effects of di-(2-ethylhexyl)phthalate in the liver. Crit Rev Toxicol. 36: 459-479. 2006.

68. Huff J. Applicability to humans of rodent-specific sites of chemical carcinogenicity: Tumors of the forestomach and of the Harderian, Preputial and Zymbal Glands induced by benzene. J Occup Med Toxicol. 1: 109-141. 1992.

69. Whysner J. Mechanism-based cancer risk assessment of butylated hydroxyanisole. Toxicol Ind Health. 9: 283-293. 1993.

70. Wurtzen G. Scientific evaluation of the safety factor for the acceptable daily intake (ADI). Case study: butylated hydroxyanisole (BHA). Food Addit Contam. 10: 307-314. 1993.

71. Rice JM, Baan RA, Blettner M, Genevois-Charmeau C, Grosse Y, McGregor DB, Partensky C, and Wilbourn JD. Rodent tumors of urinary bladder, renal cortex, and thyroid gland in IARC Monographs evaluations of carcinogenic risk to humans. Toxicol Sci. 49: 166-171. 1999.

72. Golden RJ, Holm SE, Robinson DE, Julkunen PH, and Reese EA. Chloroform mode of action: implications for cancer risk assessment. Regul Toxicol Pharmacol. 26: 142155. 1997.

73. Lock EA and Hard GC. Chemically induced renal tubule tumors in the laboratory rat and mouse: review of the NCI/ NTP database and categorization of renal carcinogens based on mechanistic information. Crit Rev Toxicol. 34: 211-299. 2004.

74. Ishmael J and Dugard PH. A review of perchloroethylene and rat mononuclear cell leukemia. Regul Toxicol Pharmacol. 45: 178-184. 2006.

75. Caldwell D. Review of mononuclear cell leukemia in F344 rat bioassays and its significance to human cancer risk: A case study using alkyl phthalates. Regul Toxicol Phamacol. 30: 45-53. 1999.

76. Lenz B, Crameri FM, Eichler DA, Schlappi B, Wiltshire HR, Wood J, and Seymour RA. Modulation of oral squamous cell carcinoma incidence in rats via diet and a novel calcium channel antagonist. Toxicol Pathol. 33: 356-364. 2005.

77. Corthals SM, Kamendulis LM, and Klaunig JE. Mechanisms of 2-butoxyethanol-induced hemangiosarcomas. Toxicol Sci. 92: 378-386. 2006.

78. Hill RN, Crisp TM, Hurley PM, Rosenthal SL, and Singh DV. Risk assessment of thyroid follicular cell tumors. Environ Health Perspect. 106: 447-457. 1998.

79. Olson H, Betton G, Robinson D, Thomas K, Monro A, Kolaja G, Lilly P, Sanders J, Sipes G, Bracken W, Dorato M,
Van Deun K, Smith P, Berger B, and Heller A. Concordance of the toxicity of pharmaceuticals in humans and in animals. Regul Toxicol Pharmacol. 32: 56-67. 2000.

80. Meek ME, Bucher JR, Cohen SM, Dellarco V, Hill RN, Lehman-McKeeman LD, Longfellow DG, Pastoor T, Seed J, and Patton DE. A framework for human relevance analysis of information on carcinogenic modes of action. Crit Rev Toxicol. 33: 591-653. 2003.

81. Gift JS. U.S. EPA's IRIS assessment of 2-butoxyethanol: the relationship of noncancer to cancer effects. Toxicol Lett. 156: 163-178. 2005.

82. Golden R, Pyatt D, and Shields PG. Formaldehyde as a potential human leukemogen: an assessment of biological plausibility. Crit Rev Toxicol. 36: 135-153. 2006.

83. Knight A, Bailey J, and Balcombe J. Animal carcinogenicity studies: 3. Alternatives to the bioassay. Altern Lab Anim. 34: 39-48. 2006.

84. Ashby J and Paton D. The influence of chemical structure on the extent and sites of carcinogenesis for 522 rodent carcinogens and 55 different human carcinogen exposures. Mutat Res. 286: 3-74. 1993.

85. Ward JM. Rat or mouse cancer bioassay-or none of the above? Toxicol Pathol. 24: 734-735. 1996.

86. Ashby J. Expectations for transgenic rodent cancer bioassay models. Toxicol Pathol. 29 Suppl: 177-182. 2001.

87. Gulezian D, Jacobson-Kram D, McCullough CB, Olson H, Recio L, Robinson D, Storer R, Tennant R, Ward JM, and Neumann DA. Use of transgenic animals for carcinogenicity testing: considerations and implications for risk assessment. Toxicol Pathol. 28: 482-499. 2000.

88. Sistare FD. Transgenic animal models that might be useful in identifying unsuspected oncogenic factors in tumour cell substrates. Dev Biol (Basel). 106: 123-131; discussion 131122, 143-160. 2001.

89. Festing MF. Use of a multistrain assay could improve the NTP carcinogenesis bioassay. Environ Health Perspect. 103: 44-52. 1995.

90. Fukushima S, Morimura K, Wanibuchi H, Kinoshita A, and Salim EI. Current and emerging challenges in toxicopathology: Carcinogenic threshold of phenobarbital and proof of arsenic carcinogenicity using rat medium-term bioassays for carcinogens. Toxicol Appl Pharmacol. 207: 225-229. 2005.

91. Ito N, Tamano S, and Shirai T. A medium-term rat liver bioassay for rapid in vivo detection of carcinogenic potential of chemicals. Cancer Sci. 94: 3-8. 2003.

92. Demierre MF, Higgins PD, Gruber SB, Hawk E, and Lippman SM. Statins and cancer prevention. Nat Rev Cancer. 5: 930-942. 2005.

93. Poynter JN, Gruber SB, Higgins PD, Almog R, Bonner JD, Rennert HS, Low M, Greenson JK, and Rennert G. Statins and the risk of colorectal cancer. N Engl J Med. 352: 21842192. 2005.

94. Cook JC, Klinefelter GR, Hardisty JF, Sharpe RM, and Foster PM. Rodent Leydig cell tumorigenesis: a review of the physiology, pathology, mechanisms, and relevance to humans. Crit Rev Toxicol. 29: 169-261. 1999. 